\title{
What Should Be Done when Listening Comprehension is Difficult?
}

\author{
Hariswan Putera Jaya \\ English Education Study Program \\ FKIP, Universitas Sriwijaya \\ Palembang, Indonesia \\ hariswan@yahoo.com
}

\begin{abstract}
Listening comprehension is a course which students majoring in English must take. It is also a part of every English competency test. It is usually considered as a difficult course just because students usually have problems in understanding what they are listening either in classrooms or in tests. There are factors which contribute to these problems. Students and teachers must recognize these problems in order to have better-listening comprehensions. There are also suggestions to solve these problems. This paper is discussing why listening comprehension is difficult and possible solutions which students and teachers can do.
\end{abstract}

Keywords-Listening; Comprehension; Problems; Solutions

\section{INTRODUCTION}

Listening is prerequisite to other language skills because the first stage in language learning is listening. It is widely known that people start to learn language by hearing sounds. From the sounds heard, he or she will try to imitate them. This activity is the first stage of a child beginning to learn to pronounce words. So, listening is the initial steps in language development. It is the most important skill in language learning. That listening is the basic skill in language learning. He also says that without listening skill, students never learn to communicate effectively because students spend $50 \%$ of the time operational in a foreign language is dedicated to listening. Furthermore, [1] notes that students from kindergarten through high school are expected to listen to 65-90 percent of the times. The importance of listening in English language learning is who states that $40-50 \%$ of communication time is spent for listening, $25-30 \%$ for speaking, about $11-16 \%$ for reading, and only about $9 \%$ for writing. However, listening does not seem to receive as much attention as the other language skills. Among four language skills -listening, speaking, reading, and writinglistening has been called the neglected skill for some decades.

A study conducted by [2] entitled "An Investigation of Listening Comprehension Problems Encountered by Saudi Students in the EL Listening Classroom" found that students who were satisfied with the instruction of reading $70 \%$, writing $25 \%$, speaking $13.3 \%$ and listening $6.7 \%$. It means that most of the students thought the listening instruction was 'below average' or 'poor' from another skill. In line with that, the report on test taker worldwide TOEIC (2014) revealed that Indonesia's listening performance was in 42nd rank out of 44 countries with the mean 234 which is under the average TOEIC score, where the score should be 500 for listening performance.
Thus, students' listening proficiency in Indonesia is still very poor.

That fact might have caused listening comprehension course received more than 10 credit hours on the average in the curriculum almost in every university with an English major in Indonesia. At our English Education Study Program, Faculty of Teacher Training and Education, Universitas Sriwijaya, there are 12 credit hours for listening comprehension course which students must take starting from the first until the fourth semester. In spite of the fact that listening comprehension has more credit hours than other courses and teaching and learning strategies applied by the lecturers, students still have difficulties in listening. Ref. [2] states that EFL students have crucial problems in listening comprehension because universities pay attention to grammar, reading, and vocabulary. Listening and speaking skills are not significant parts of many books and teachers do not consider these skills in their classes. Stated that listening is not very important for both teachers and students and teachers test not to teach listening and students learn listening not listening comprehension. Consequently, it remains the most neglected aspect of language teaching. Ref. [2] further emphasized that comprehending speech is a very difficult activity for students. Students face a lot of problems when they listen to a language. If teachers are expected to help students improve their listening comprehension, they should comprehend their listening difficulties in understanding spoken passages. In this paper, problems usually encountered by students in listening comprehension classes are going to be discussed.

\section{COMMON PROBlems FACED By STUdENTS IN LiSTENING COMPREHENSION}

There are many factors that can cause listening difficulties. They are external and internal in terms of what contributes to them. According to [3], students may encounter difficulties in listening comprehension processes because of the following reasons:

\section{A. Quality of Recorded Materials}

In some classes, teachers use some recorded materials that usually have been rerecorded for more than three times. These will reduce the quality of the sounds which eventually will affect the students in trying to comprehend the listening materials. 


\section{B. Cultural Differences}

Students must be familiar with the cultural knowledge of the language that has a significant effect on the students' understanding. If the listening task involves completely different cultural materials then the students may have critical problems in their comprehension. It is the responsibility of teachers to give background knowledge about the listening activities in advance.

\section{Accent}

That too many accented speech can lead to an important reduction incomprehension. In addition, [4] stated that $66 \%$ of students mentioned a speaker's accent as one of the most significant factors that affect listener comprehension. Unfamiliar accents both native and non-native can cause serious problems in listening comprehension and familiarity with an accent helps students' listening comprehension. Similarly, [5] mentioned that when listeners hear an unfamiliar accent such as Indian English for the first time after studying only American English will encounter critical difficulties in listening. This will certainly interrupt the whole listening comprehension process and at the same time, an unfamiliar accent makes comprehension impossible for the listeners.

\section{Unfamiliar Vocabulary}

When listening materials contain known words it would be very easy for students to them. If students know the meaning of words this can arouse their interest and motivation and can have a positive impact on the students' listening comprehension ability. A lot of words have more than one meaning and if they are not used appropriately in their appropriate contexts students will get confused.

\section{E. Length and Speed of Listening}

It is very difficult for lower level students to listen more than three minutes long and complete the listening tasks. Short listening passages make easy listening comprehension for students and reduce their tiredness. Speed can make listening passage difficult. If the speakers speak too fast students may have serious problems to understand L2 words. In this situation, listeners are not able to control the speed of speakers and this can create critical problems with listening comprehension. Despite the fact that we can cope with missing whole chunks of speech having a conversation on a noisy street in our own language, many people don't seem to be able to transfer that skill easily to a second language. One method of tackling this is to show them how to identify the important words that they need to listen out for. In English, this is shown in an easy-to-spot way by which words in the sentence are stressed. Another is to give them one very easy task that you know they can do even if they don't get $90 \%$ of what is being said to build up their confidence, such as identifying the name of a famous person or spotting something that is mentioned many times.

\section{F. Physical conditions}

Sometimes inconvenience of classrooms affects students listening comprehension. In the large classrooms, students who are sitting on the back rows may not hear the recording as students sit in front. Students who prefer to stay next to the windows also affected by the noise that comes from outside. As a teacher, we have to take into account all these conditions in a body. The size of the classroom also makes difficult for a teacher to manage all class in a group activity or to get feedback from students. The temperature of the class can be counted as a factor that makes listening comprehension difficult. The class that does not have air conditioner or heater may be too hot in summer or too cold in winter.

\section{G. Lack of concentration}

Students' motivation is one of the crucial factors that affect listening comprehension. It can be difficult for students maintaining the concentration in a foreign language learning classroom. In listening comprehension, even the smallest pause inattention may considerably spoil comprehension. When students find the topic of the listening text interesting, comprehending would be easier. For all that, students find listening very boring even if they are interested in the topic because it needs a huge amount of effort in order to not miss the meaning.

\section{WHAT IS THE SOLUTION?}

The following are solutions suggested by [6]:

- Listening activities should be provided based on the students' needs and teachers should provide authentic listening materials for students that help them understand better the natural speech uttered by native speakers.

- Teachers should design listening tasks that arouse students' interest and help them learn listening skills and strategies. These tasks not only test the students' listening comprehension but also motivate them to use various types of listening strategies in order to gain the maximum benefits in doing their activities.

- Teachers should provide students with different types of input like lectures, radio news, films, TV plays, announcements, everyday conversation, and interviews.

- Teachers should familiarize their students with the rules of pronunciation in order to help them hear the different forms of rapid natural speech and ask them to imitate native speakers' pronunciation.

- Teachers should help their students to be familiar with the accents of different native speakers. Due to the fact that native speakers have specific accents, it is necessary for students to recognize the differences between American and British accents.

- Listening activities should be presented according to their level of complexities; that is, listening activities should be provided from the very simple texts to the lower level students and moved to the very complicated authentic materials to the advanced students.

- Teachers should provide background knowledge and linguistic knowledge to their students while listening to different listening materials. 
- Teachers should give their students the necessary feedback on their performance because it can promote their error correction and increase their motivation, and help them to develop their confidence in listening exercises.

- Teachers should help their students to develop the necessary skills of listening comprehension like listening for understanding particular information, listening for the main ideas, explanation, and inference, listening for intended meaning through providing different tasks and activities at different levels.

- Teachers should use body language such as pointing and facial expressions to reinforce oral messages in their students.

- Teachers should provide opportunities for developing topdown and bottom-up processing skills because top-down activities motivate students to discuss what they already know about a topic and bottom-up activities give confidence in the understanding of the components of the language such as sounds, words, intonation, and grammatical structures.

- Teachers should encourage their students to develop listening strategies. Predicting, asking for clarification, and using non-verbal cues are some examples of these strategies that improve students' listening comprehension ability.

- Teachers should be appropriately trained in speaking skills. Listening is related to good pronunciation; therefore, teachers should have good and acceptable pronunciation which can help students to become better listeners.
- Teachers should ask their students to always listen to music, documentaries, and news on the radio and television, talk to native speakers face to face or on the Internet so that they can create and reinforce a good habit of listening in themselves.

\section{CONCLUSION}

It can be concluded that listening comprehension course is a difficult course because students need good listening environments, good recording quality, excellent linguistic competence, and intensive exposure towards English to have satisfying listening skill. Through intensive listening practices, students can improve their listening comprehension.

\section{REFERENCES}

[1] Gilbert, M. B. (1988). Perceptions of listening behaviors of school principals. School Organisation, 9, 271- 282.

[2] Azmi, B. M., Celik, B., Yidliz, N., \& Tugrul, M. C. (2014). Listening Comprehension Difficulties Encountered by Students in Second language Learning Class. Journal of Educational and Instructional Studies in the Wor 1 d, 4(4), 1-6.

[3] Buck, G. (2001). Assessing Listening. Cambridge: Cambridge University Press.

[4] Gilakjani, P. A. (2012) The significant role of multimedia in motivating students' interest in English language learning. I.J.Modern Education and Computer Science, 4, 57-66.

[5] Goh, C. (1999). Teaching Listening in the Language Classroom. Singapore: SEAMEO Regional Language Centre.

[6] Hamouda, A. (2013). An investigation of listening comprehension problems encountered by Saudi students in the el listening classroom. 